AperTO - Archivio Istituzionale Open Access dell'Università di Torino

\title{
Comparative corporate governance and international portfolios
}

\section{This is the author's manuscript}

Original Citation:

Availability:

This version is available http://hdl.handle.net/2318/144964

since 2016-07-01T11:53:53Z

Published version:

DOI:10.1080/1351847X.2014.902857

Terms of use:

Open Access

Anyone can freely access the full text of works made available as "Open Access". Works made available under a Creative Commons license can be used according to the terms and conditions of said license. Use of all other works requires consent of the right holder (author or publisher) if not exempted from copyright protection by the applicable law. 
This is the author's final version of the contribution published as:

Maela Giofre'. Comparative corporate governance and international portfolios. EUROPEAN JOURNAL OF FINANCE. 22 pp: 756-781. DOI: $10.1080 / 1351847 X .2014 .902857$

The publisher's version is available at:

http://www.tandfonline.com/doi/full/10.1080/1351847X.2014.902857

When citing, please refer to the published version.

Link to this full text:

http://hdl.handle.net/2318/144964 


\title{
Comparative corporate governance and international portfolios*
}

\author{
Maela Giofré ${ }^{\dagger}$ \\ University of Torino and CeRP-Collegio Carlo Alberto
}

\begin{abstract}
The impact of foreign investor protection on portfolio choices negatively depends on the degree of domestic investor protection enjoyed by the investor. The coefficient of foreign countries' investor protection scaled by world average is therefore not constant across investing countries. The ratio foreign to domestic investor protection rights index is shown instead to be a plausible common driver of international portfolios. Phrased differently, domestic investor protection replaces the world average corporate governance in the construction of the relevant measure driving international portfolio choice. If the weight attached to the domestic factor in the construction of the average measure is large enough it can determine, almost completely, the world average corporate governance. This outcome is consistent with a setting in which the investor, strongly hit by information constraints, places a disproportionally large weight on domestic information considered as more reliable because observed at a higher precision.

Keywords: International portfolio investments, Investor Protection Rights, Home bias, Behavioral Finance

JEL Classifications: G02, G11, G15, G30
\end{abstract}

${ }^{*}$ I am grateful to Trevor Chamberlain, Jayant Ganguli, Sarmistha Pal and participants in the 16th INFER Annual Conference (Pescara), 6th IFABS 2014 Conference (Lisbon), World Finance Conference (Venice) and the 29th Annual Congress of the European Economic Association (Toulose) for helpful comments. I am indebted with two anonymous referees that helped me in improving the paper. The usual disclaimer applies.

${ }^{\dagger}$ University of Torino (Department of Economics and Statistics "Cognetti de Martiis") and CeRP-Collegio Carlo Alberto. Lungo Dora Siena 100/A 10153 Torino, Italy. Email: maela.giofre@unito.it; Telephone: +390116704980; Fax: +390116703895 


\section{Introduction}

Nowadays investors still display a strong preference for domestic assets notwithstanding the benefits from international diversification of equity portfolios documented long ago (Markowitz (1952); Sharpe (1964); Grubel (1968); Levy and Sarnat (1970); Solnik (1974)). Several attempts have been made to rationalize the so-called "home bias" phenomenon (Lewis (1999); Karolyi and Stulz (2003)): proposed explanations refer to barriers to international investment (Stulz (1981); Tesar and Werner (1995)), behavioral bias consisting in over-optimism of domestic investors toward domestic assets (French and Poterba (1991); Strong and Xu (2003); Li (2004)), hedging of background risk (Cooper and Kaplanis (1994); Baxter and Jermann (1997); Pesenti and van Wincoop (2002)), information asymmetry between domestic and foreign investors (Gehrig (1993); Chan et al. (2005); Portes and Rey (2005)).

Recent literature has placed particular emphasis on the role played by investor protection rights. Previous work originating from La Porta et al. (1998) underlines how investor protection affects financial market development, that is, the supply of equity, leaving the demand side mostly unexplored. This latter perspective is relevant insofar as one accounts for heterogeneity across investors.

Leuz et al. (2009) investigate the impact of firm-level corporate governance on foreign holdings and find that US investors invest less in foreign firms with poor outsider protection and opaque earnings. In particular, they find that foreign holdings in firms with poor governance are driven by information asymmetry. Giofré (2013) highlights how laws protecting different interests asymmetrically affect foreign stakeholders. More specifically, foreign shareholders appear to appreciate strong creditor rights, which potentially mitigate the riskiness of projects, while bondholders are negatively affected by strong shareholder rights, which might induce the firm to engage in excessively risky behavior. Giannetti and Koskinen (2010) show that investor protection impacts financial market development by influencing the demand for equity, because different classes of investors - controlling shareholders and outside shareholders- can differ in the benefits accruing to them and therefore in their willingness to pay for stocks.

The asymmetric impact of corporate governance on different categories of investors (Leuz et al. (2009); Giannetti and Koskinen (2010); Giofré (2013)) emphasizes that its impact may crucially depend on the nature of the investor. In this paper we are particularly interested in the role played by domestic investor protection, that is legislation protecting minority shareholders at home.

Giannetti and Koskinen (2010) include domestic investor protection in the analysis and find that it 
influences the portfolio share invested in domestic assets: in weak investor protection countries, portfolio investors' foreign holdings are larger than in countries where minority shareholders are better protected.

However, their analysis assumes that corporate governance evenly affects all foreign investors. Recently Giofré (2014) has shown that the hypothesis of an even impact of corporate governance on foreign investment is rejected by the empirical evidence. Conversely, the stronger is the domestic protection of shareholder rights the lower is the impact of foreign corporate governance on portfolio investment. Giofré (2014) brings to light a perverse effect of strong domestic investor protection rules: they dampen the attractiveness of well protected foreign investment relatively more than that of poorly governed countries' assets. Countries with higher corporate governance standards are therefore relatively more underweighted in portfolios held by better regulated investing countries than in portfolios held by countries displaying low investor protection.

In this paper we aim to find a testable explanation of the role of domestic corporate governance in dampening the effect of foreign investor protection legislation.

Since information asymmetries between foreign and local investors are particularly severe with respect to the evaluation of a firm's governance structure (Leuz et al. (2009); Kho et al. (2009)), investors are supposed to observe domestic corporate governance with a much higher precision than foreign corporate governance. As a consequence, investors may attach a superior degree of reliability -and therefore a higher weight- to the index of domestic investor protection. If this weight in the world average index is large enough then the average can be approximated by a function of the domestic index. A proposed measure is the ratio foreign to domestic antidirector rights index. This is a measure of "comparative corporate governance", a concept close to the "comparative ignorance" theory developed by Fox and Tversky (1995) and Fox and Weber (2002): what matters for international portfolio choice is the protection of shareholder rights in the foreign country relative to the protection afforded at home. The innovative contribution of the present paper hinges precisely on the proposal of an alternative measure of corporate governance and on the implementation of a rigorous test of its interpretation and effectiveness.

The remainder of this paper is organized as follows. Section 2 describes the conceptual framework, the estimable equation and its main testable implications. Section 3 presents the data and some descriptive statistics. Section 4 illustrates the results. Section 5 concludes. 


\section{A conceptual framework}

Our framework hinges on equilibrium portfolio allocations in which investors are supposed to face different costs from investing in various financial markets. According to Gehrig (1993), foreign investments appear on average more risky to domestic investors-leading to an information-based justification to home biasand portfolios differ among investors depending on their perceived variance-covariance matrix. We adopt this approach allowing for a different investor-specific perceived variability of return for each foreign index included in the investment opportunity set.

Absent any investor-specific factor, the "unbiased" portfolio holding of an asset depends, as in standard portfolio choice theory, on asset characteristics (risk and return) ${ }^{1}$. When considering equilibrium asset holdings without investment barriers, all investors ought to hold the same portfolio, i.e., the value-weighted portfolio, in which each asset is weighted according to its share in world stock market capitalization. The same portfolio is still universally optimal in equilibrium even in the presence of investment barriers, provided that these barriers identically affect all investors. Conversely, heterogeneity in investment barriers generates a wedge between the investor-specific portfolio and the value-weighted portfolio. This wedge depends, in particular, on the distance between the pair-specific investment barrier of country $l$ investing in country $j$ and the average barrier calculated over all countries investing in the same asset $j$.

The optimal portfolio weight in asset $j\left(w_{l j}\right)$ by country $l$ is

$$
w_{l j}=\frac{1}{D_{l j}} M S_{j} \quad \text { or } \quad \frac{w_{l j}}{M S_{j}}=\frac{1}{D_{l j}}
$$

where $M S_{j}$ is the market share of asset $j$ in the world market capitalization and $D_{l j}$ represents the relative (to the world average) investment barriers of country $l$ investing in asset $j^{2}$. Investors residing in country $l$ will demand a share of asset $j$ greater than its market share in proportion to $\frac{1}{D_{l j}}$, that is the reciprocal of the relative investment barrier ${ }^{3}$.

The ratio $\frac{w_{l j}}{M S_{j}}$ can be interpreted as the foreign bias in asset $j$ of a representative investor in country $l$. A portfolio share $w_{l j}$ larger than $j$ 's market share signals that asset $j$ is over-weighted in country $l$ 's portfolio and vice versa.

\footnotetext{
${ }^{1}$ Details on the derivation of our stylized model are available upon request from the author.

${ }^{2}$ Note that if $D_{l j}=1$, i.e., if the investment barrier of country $l$ in country $j$ is equal to the average, then $M S_{j}$ is optimally held in equilibrium.

${ }^{3}$ Our theoretical framework is equivalent to the return-reducing approach of Cooper and Kaplanis (1994) and Chan et al. (2005). In fact, in equilibrium, what matters is the investment barrier relative to the average.
} 


\subsection{Estimable equation and testable implications}

\subsubsection{Estimable equation}

To estimate (1) we must provide an empirical counterpart to the variable $D_{l j}$, which is not directly observable. Our final estimable regression can be rewritten as follows

$$
\left(\frac{w_{l j}}{M S_{j}}\right)=\alpha+\sum_{i=1, . ., I} \beta^{i} X_{l j}^{i}+\sum_{n=1, . ., N} \lambda^{n} Y_{l j}^{n}+\varepsilon_{l j}
$$

We consider $i$ regressors, denoted by $X_{l j}$ and $n$ dummy variables $Y_{l j}$ to capture pair-specific investment barriers.

To estimate the above parameters, we adopt a feasible Generalized Least Squares specification which assumes the presence of cross-section heteroskedasticity and includes fixed effects for investing countries, time dummies, with a cross-section weight correction of the variance-covariance matrix.

When including $K$ variables capturing destination-specific factors our specification becomes

$$
\left(\frac{w_{l j}}{M S_{j}}\right)=\alpha+\sum_{i=1, . ., I} \beta^{i} X_{l j}^{i}+\sum_{n=1, . ., N} \lambda^{n} Y_{l j}^{n}+\sum_{k=1, . ., K} \delta^{k} Z_{j}^{k}+\varepsilon_{l j}
$$

The main variable of interest in the paper is an index of minority investor protection. The index of shareholder rights (or antidirector rights, ADR henceforth) originates from La Porta et al. (1998) and measures how strongly the legal system favours minority shareholders against managers or dominant shareholders in the corporate decision making process. We adopt the "corrected" ADR index $\left(S_{-} A D R_{j}\right)$ as refined in Spamann (2010). ${ }^{4}$ The author, by a reexamination of the legal data, derives more precise estimates of ADR leading to corrections for forty-three out of the forty-six countries analyzed in La Porta et al. (1998). The difference between corrected and original values is such that many empirical results established using the original indexes may not be replicable with corrected values.

We isolate the destination country $j$ 's ADR out of the pool of $K$ destination country factors to separately discuss its coefficient. For consistency with the conceptual framework illustrated above, all covariates enter the equation in relative terms, i.e., scaled by their world average. Therefore, our econometric equation can be specified as follows:

\footnotetext{
${ }^{4}$ See Spamann (2010) for further details on the corrected index.
} 


$$
\left(\frac{w_{l j}}{M S_{j}}\right)=\alpha+\sum_{i=1, . ., I} \beta^{i} X_{l j}^{i}+\sum_{n=1, . ., N} \lambda^{n} Y_{l j}^{n}+\sum_{k=1, . ., K-1} \delta^{k} Z_{j}^{k}+\delta^{K}\left(S_{-} a d r_{j}\right)+\varepsilon_{l j}
$$

where $S_{-} a d r_{j}$ is the Spamann ADR index $\left(S_{-} A D R_{j}\right)$ scaled by its world average.

Standard asset pricing models assuming a representative agent predict that differences in observable characteristics of the asset, such as investor rights and financial development of the issuing firm or country, should be capitalized in share prices such that investing in any stock will be a fair investment regardless of the issuer's level of investor protection (Dahlquist et al. (2003)). All equilibrium factors, common to domestic and foreign investors, are captured on the left-hand side of equation (2) by the market share, which is jointly determined with the market price in equilibrium.

However, when accounting for heterogeneity across investors, the equilibrium price discount discloses only the average behavior thus inducing under- or over-investment by those investors for which the price discount is, respectively, too low or too high (Leuz et al. (2009); Giannetti and Koskinen (2010)). In particular, this price discount is likely not sufficient for investors, such as foreign ones, who plausibly face information problems beyond those of domestic investors (Leuz et al. (2009)). The home bias puzzle can be read as evidence of the asymmetric perception of asset characteristics by home and foreign investors thus breaking the representative agent hypothesis ${ }^{5}$. In the presence of heterogeneity, a wedge emerges between the actual position $(w)$ and the market share. If all investors, domestic and foreign, equally perceived the level of investor protection in country $j$, this would be perfectly priced and should have no impact on portfolio allocation decisions. The evidence of a significant positive role played by investor protection in shaping foreign portfolios precisely underlines its stronger impact for foreign investors.

However, further heterogeneity sources may also exist within the group of foreign investors, such as differences in investor protection legislation across investing countries. This heterogeneity dimension matters insofar as, for instance, domestic legislation affects investors' evaluation of foreign protection. In this case, the effect exerted by foreign corporate governance would be correlated with domestic investor protection and thus differences in the incentives to international portfolio diversification would emerge.

\subsubsection{Testable implications}

Giofré (2014) finds that the sensitivity of foreign investment to foreign corporate governance is significantly

\footnotetext{
${ }^{5}$ Gehrig (1993) and Kang and Stulz (1997), among others, focus on the role played by information asymmetry in determining the home bias evidence. See Lewis (1999) for a comprehensive review on the home bias literature.
} 
lower for investing countries with stronger corporate governance rules ${ }^{6}$. We need to test if this evidence is robust across different sample and regression specifications. Indeed, differently from Giofré (2014), in this paper, on the one hand, the sample encompasses the first stage of the crisis and, on the other hand, the regression specification does control for investing country fixed effects, which are not included in Giofré (2014) because the domestic investor protection -an investing-country specific facor- is included linearly in the estimated equation.

To test this hypothesis in our sample we first check if $S_{-} a d r_{j}$ equally affects all foreign investing countries, that is, if the coefficient $\delta^{K}$ does not vary across investing countries featuring different degrees of investor protection.

If our findings are in line with Giofré (2014) we should observe that the coefficient $\delta^{K}$ estimated in the sub-sample of investing countries featuring ADR below (or equal to) the median, is larger than the coefficient estimated in the sub-sample of investing countries featuring ADR above (or equal to) the median. We add an interaction term between foreign $\left(S_{-} a d r_{j}\right)$ and domestic ADR $\left(S_{-} a d r_{l}\right)$ to estimate, over the whole sample of investing countries, the indirect impact of $S_{-} a d r_{l}$ on international portfolios ${ }^{7}$.

$$
\left(\frac{w_{l j}}{M S_{j}}\right)=\alpha+\sum_{i=1, . ., I} \beta^{i} X_{l j}^{i}+\sum_{n=1, . ., N} \lambda^{n} Y_{l j}^{n}+\sum_{k=1, . ., K-1} \delta^{k} Z_{j}^{k}+\delta^{K}\left(S_{-} a d r_{j}\right)+\gamma\left(S_{-} a d r_{j} \cdot S_{-} a d r_{l}\right)+\varepsilon_{l j}
$$

A coefficient

$$
\gamma<0
$$

(preliminary condition)

would imply that more protective corporate governance standards at home make investors less sensitive to foreign corporate governance when internationally diversifying their portfolios.

Under the assumption that the above condition holds, the focus of the present paper is providing a testable interpretation to this evidence. We recall that $S_{-} a d r_{j}$ is constructed as the Spamann antidirector rights index $\left(S_{-} A D R_{j}\right)$ scaled by the world average index $\left(\overline{S_{-} A D R}\right)$, representing the universal benchmark against which foreign countries are confronted.

\footnotetext{
${ }^{6}$ The time span covered in Giofré (2014) is 2001-2006, that is a pre-crisis period.

${ }^{7}$ Notice that the inclusion of investing-country fixed effects prevents us from including any investor-specific variable, such as the domestic investor protection.
} 


$$
S_{-} a d r_{j}=\frac{S_{-} A D R_{j}}{\overline{S_{-} A D R}}
$$

We suspect that the world average index is differently perceived by investors because of the weight each investor attaches to the various components of the index. Since information asymmetries between foreign and local investors are particularly severe with respect to the evaluation of a firm's governance structure (Leuz et al. (2009); Kho et al. (2009)), investors are likely to observe domestic corporate governance at a much higher precision than foreign corporate governance. As a consequence, investors may attach a superior degree of reliability -and therefore a higher weight- to the index of domestic investor protection. If the domestic weight in the world average index is large enough, the average can be approximated by a function of the domestic index.

$$
\overline{S_{-} A D R} \simeq f\left(S_{-} A D R_{l}\right)
$$

Then the term $S_{-} a d r_{j}$ in equation (4) is replaced by $\frac{S_{-} A D R_{j}}{f\left(S_{-} A D R_{l}\right)}$ and the equation to be estimated becomes

$$
\left(\frac{w_{l j}}{M S_{j}}\right)=\alpha+\sum_{i=1, . ., I} \beta^{i} X_{l j}^{i}+\sum_{n=1, . ., N} \lambda^{n} Y_{l j}^{n}+\sum_{k=1, . ., K-1} \delta^{k} Z_{j}^{k}+\hat{\delta}^{K} \frac{S_{-} A D R_{j}}{f\left(S_{-} A D R_{l}\right)}+\varepsilon_{l j}
$$

The resulting variable is a measure of "comparative corporate governance", a concept close to "comparative ignorance" (Fox and Tversky (1995), Fox and Weber (2002)): what matters for portfolio choice is the protection of shareholder rights in the foreign country relative to the protection afforded at home. The innovative contribution of the present paper hinges precisely on the proposal of an alternative measure of corporate governance and on the implementation of a rigorous test of its interpretation and effectiveness.

To test the validity of our theory on "comparative corporate governance", after the "preliminary condition", we need three additional conditions to be verified.

We need first to verify the consistency of our interpretation ("consistency condition"). If domestic corporate governance dampens the effect of the destination country ADR because it approximates the world average, then the weight attached to $S_{-} A D R_{l}$ must be, at the largest, equal to one. In this extreme case, the world average index would coincide with the domestic index. In all intermediate cases, a variation in the domestic index should induce a less than proportional variation in the function $f\left(S_{-} A D R_{l}\right)$.

In more formalized terms, let us consider a sequence $f_{n}$ of continuous and strictly increasing functions 
of $S_{-} A D R_{l}$

$$
\mathrm{f}_{n}\left(\mathrm{~S}_{-} \mathrm{ADR}_{l}\right):[1, \infty) \longrightarrow[0 ; \infty)
$$

where, by definition, 1 is the lower bound for $S_{-} A D R_{l}$ according to Spamann (2010).

To corroborate our interpretation, the linear function $f_{h}\left(S_{-} A D R_{l}\right) \equiv S_{-} A D R_{l}$ must be weakly dominating the sequence of functions $f_{n}$, that is,

$$
\mathrm{f}_{h}\left(\mathrm{~S}_{-} \mathrm{ADR}_{l}\right) \equiv \mathrm{S} \_\mathrm{ADR}_{l}=\sup _{n}\left(\mathrm{~S}_{-} \mathrm{ADR}_{l}\right) \quad \text { (consistency condition) }
$$

Any other function which dominates $S_{-} A D R_{l}$ would be in contrast with our theory. Conversely, there may exist alternative functions, dominated by $f_{h}$, which are consistent with our theory since they imply that the weight attached to the domestic index is lower than one.

In addition, the proposed "comparative corporate governance" measure must contribute to explain the role of corporate governance in international portfolio choice ("significativity condition"). To test its role, we need to show that the data reject the null hypothesis that the coefficient attached to this measure is equal to zero:

$$
\hat{\delta}^{K} \neq 0
$$

(significativity condition)

The final condition is related to the effectiveness of the measure proposed ("effectiveness condition"). If the standard measure scaled by the world average index fails to capture a universal driver of corporate governance, we need to show that the alternative measure we propose reaches the goal. We need to ascertain that the coefficient $\hat{\delta}^{K}$ of the "comparative corporate governance" measure in equation (6) is in fact invariant across investing countries displaying various level of domestic protection. The following condition must hold:

$$
\left.\hat{\delta}^{K}\right|_{S_{-} A D R_{l} \leq \text { median }}=\left.\hat{\delta}^{K}\right|_{S_{-} A D R_{l} \geq \text { median }}
$$

(effectiveness condition)

In sum, our empirical strategy will follow four steps. First, we verify the "preliminary condition": since the coefficient of $S_{-} a d r_{j}$ in equation (4) must be lower for investing countries with stronger investor protection, the coefficient $\gamma$ of the interaction term $\left(S_{-} a d r_{j} \cdot S_{-} a d r_{l}\right)$ must be negative, as shown by Giofré (2014). As a second step, we need to propose an alternative specification of the index that satisfies 
the "consistency condition", which would support our interpretation of domestic investor protection as an investor-specific proxy for the world average index. Third, we need to show that the coefficient of the index proposed is statistically significant ("significativity condition"). Finally, also the "effectiveness condition" must be verified: the proposed measure should display the desirable property of being invariant to the degree of shareholder protection at home.

\section{$3 \quad$ Data and descriptive statistics}

\subsection{Data}

We consider foreign portfolio investments in equities by 14 major investing countries-Austria, Belgium, Canada, Denmark, Finland, France, Germany, Italy, Japan, the Netherlands, Spain, Sweden, United Kingdom, and the United States-for the period 2001-2008. We adopt the CPIS (Coordinated Portfolio Investment Survey, by IMF) dataset which has been exploited in many recent papers (Lane and Milesi-Ferretti (2007); Sorensen et al. (2007); Fidora et al. (2007); Foad (2011)). This survey collects security-level data from the major custodians and large end-investors. Portfolio investment is broken down by instrument (equity or debt) and residence of issuer, the latter providing information on the destination of portfolio investment. 8

The opportunity set is made up of 20 destination stock markets: Australia, Austria, Belgium, Canada, Denmark, Finland, France, Germany, Hong Kong, Italy, Japan, Korea, Mexico, Netherlands, Portugal, Singapore, Spain, Sweden, United Kingdom, and the United States. ${ }^{9,10}$

The full set of regressors included in the analysis is described in detail in Appendix A.2, while their impact on portfolio investment is discussed in next sections.

\footnotetext{
${ }^{8}$ While the CPIS provides the most comprehensive survey of international portfolio investment holdings, it is still subject to a number of important caveats. See www.imf.org/external/np/sta/pi/datarsl.htm for more details on the survey.

${ }^{9}$ Since we focus on foreign portfolio allocation, the destination stock markets number 19, since the domestic country is excluded from analysis. The GLS regression is run, therefore, on 2110 observations (19 observations for each year for each investing country, with some missing values). As a common practice, Switzerland, Luxembourg and Ireland are excluded from the sample since considered as mainly off-shore financial centres.

${ }^{10}$ Notice that even though our investment opportunity set is restricted to 20 out of more than 235 countries available in the CPIS dataset, excluded countries cover on average less than 3 percent of total stock market participation (ranging from less than 1 percent in Canada to slightly more than 6 percent in Austria).
} 


\subsection{Descriptive statistics}

Table 1 shows the average domestic portfolio share held by each investing country in the period 2001-2008. For reference, we report in the second column the average market share. The "home bias" statistic, a widely used measure of underdiversification, can be computed as the ratio of domestic share to market share: a value larger than 1 signals a disproportionate investment in domestic assets. As expected, all countries display home bias: they invest internally more than 50 percent of their portfolio, with Austria, Belgium and Netherlands as the only exceptions.

*TABLE 1 about here*

Table 1 also reports $S_{-} A D R_{l}$, the Spamann ADR index (Spamann (2010)) associated with each investing country.

At the bottom of the table we compute the correlation coefficient of the $S_{-} A D R_{l}$ index with, alternatively, domestic share investment, market share and home bias (domestic share/market share). The coefficient is not statistically different from zero in all cases signaling that the degree of investor protection at home does not per se induces more or less domestically concentrated portfolios.

In Table 2 we focus our attention on foreign portfolio shares. In columns (a) and (b) of Table 2, we report the average foreign share and the corresponding fraction of world stock market capitalization, respectively. The foreign bias is computed as the ratio of actual share to market share, following equation (1). Column (c) shows the average foreign bias in several destination countries, obtained by averaging across investing countries the foreign bias: a value equal to 1 implies that foreign assets enter portfolios with a weight equal to their relative stock market share. The average foreign bias almost systematically below unity means that

foreign assets are generally underweighted in portfolios and this is the mirror image of the strong home bias reported in Table 1. Beyond this common picture of major stock markets, a notable degree of heterogeneity in bias toward various foreign assets emerges: there might exist country-specific factors-among which are investor protection laws-making some countries more attractive than others to foreign investors.

*TABLE 2 about here*

Column (d) reports the standard deviation of the foreign bias around the average, a measure providing information on the dispersion of the foreign bias displayed by various investing countries with respect to the same asset. Also along this dimension the degree of dispersion is quite large being the standard deviation 
almost 90 percent of the average bias for stocks. This points to the important role of investing countries' specificities affecting international diversification patterns. Let us emphasize that the foreign bias consists of the foreign investment scaled by the market share: a large foreign bias then can be the result of a high foreign investment, a low market share or both of them. For instance, Sweden and Finland are the only two countries displaying an average foreign bias larger than one, and this is mainly due to their relatively low market share. Moreover, these countries also display an anomalous high variability in foreign bias due to the exceptionally high investments by Scandinavian countries.

The correlation coefficient between the $S_{-} A D R_{l}$ index and the average foreign share, the market share, the average foreign bias, and the standard deviation of the foreign bias is never statistically significant thus suggesting that the impact of corporate governance on international portfolios needs to be properly seized in a multivariate regression model which accounts for other relevant factors.

\section{Results}

The statistics on foreign bias discussed above reveal a great deal of heterogeneity across both destination and investing countries and point to the importance of analyzing the specific allocation pattern of various foreign investors. The existence of national specificities makes crucial to control for pair-specific factors whose impact cannot be priced by the market. Before considering the joint effect of foreign and domestic ADR let us account for other standard factors influencing international portfolio investments.

\subsection{Proximity regressors}

The literature has stressed how market proximity captures the influence of asymmetric information on investor portfolio choice (Gehrig (1993); Brennan and Cao (1997); Kang and Stulz (1997)).

Many empirical contributions find that the cultural and geographic proximity of the market has an important influence on investor stock holdings and trading (Grinblatt and Keloharju (2001); Chan et al. (2005); Portes and Rey (2005)).

*TABLE 3 about here*

In column (1) of Table 3 we regress foreign portfolio bias $\left(w_{l j} / M S_{j}\right)$ on standard gravity variables such as distance, common border dummy and common language dummy. The common border (language) dummy 
takes the value 1 if the investing and destination country share a common border (language) and 0 otherwise. The first two variables, distance and common border, simply capture the physical distance between investing and destination country. Since transactions in financial assets are "weightless", a role for distance may be found only if it has informational content (Portes and Rey (2005)). ${ }^{11}$ The role of the common language dummy is immediately interpretable, since foreign languages make collecting information more difficult. These variables play an economically and statistically significant role in explaining the dependent variable with a particularly strong impact of the common border dummy, quantitatively even larger (0.51) than the median value taken by the foreign bias variable $(0.42)$.

We then account for other variables capturing pair-specific linkages: namely, common currency area (EMU), and common legal origin. The EMU dummy takes the value 1 if the investing and destination countries are EMU members and 0 otherwise. The coefficient is positive and significant and its effect is quite large: EMU membership boosts foreign bias by 0.31 compared to non member countries. Our findings are consistent with the evidence of Lane and Milesi-Ferretti (2007) and Balta and Delgado (2009), who find, as a result of monetary integration, a notable increase in foreign investments in the Euro area by EMU countries.

Finally, sharing the same legal origin might encourage cross-border investment since there is less fear of unknown factors (Vlachos (2004); Lane (2006); Guiso et al. (2009)). We include a dummy variable taking the value 1 if the investing and destination countries share the same legal family (English, French, German or Scandinavian) and 0 otherwise. The coefficient is positive as expected: sharing a common legal origin determines an increase in the foreign bias by 0.07 percentage points. At a first glance, the economic impact of this variable may appear almost negligible but is quite relevant in relative terms as it determines an increase by almost $20 \%$ of the median value taken by the dependent variable.

Overall, these pair-specific factors have a quite strong explanatory power of foreign portfolio bias, as confirmed by the sizeable adjusted- $\mathrm{R}^{2}(0.48)$.

\subsection{Foreign and domestic corporate governance}

After controlling for proximity regressors, we shift our analysis to the ADR index, the variable representing the focus of our paper.

\footnotetext{
${ }^{11}$ A separate role for the border dummy can be found insofar as this variable is considered as "correcting" the distance variable, which is measured as the great circle distance between the capital cities of the destination and investing countries.
} 
The results on the positive effect of shareholder rights on foreign investments are shown in column (2) of Table 3 and are qualitatively consistent with recent evidence reported by Leuz et al. (2009), Thapa and Poshakwale (2011) and Giofré (2013). Specifically, we find that an increase by 1 of the ratio $S_{-} A D R_{j}$ index to the world average (i.e., $S_{-} a d r_{j}$ ) induces a twelve percentage points increase in foreign bias. ${ }^{12}$

The evidence that $S_{-} a d r_{j}$ significantly impacts foreign investment implies that, within the universe of investors holding assets $j$, domestic and foreign investors differ in the evaluation of the same factor, that is, they asymmetrically evaluate investor protection rights. This outcome can be easily rationalized from a foreign investor's perspective because, as the literature shows, foreign investors are relatively more severely affected by information asymmetry (Leuz et al. (2009)). Such investors plausibly perceive assets as more risky than do domestic investors (Gehrig (1993)), such that any institutional devices allowing investors to reduce riskiness are more valuable to foreigners than to domestic investors.

The strong heterogeneity of portfolio holdings across foreign investing countries suggests a divergent evaluation of the same asset characteristics not only between foreign and domestic investors but also among foreign investors. We conjecture that the ADR afforded in the investing country can be a pivotal factor to explain this evidence. ${ }^{13}$

We split our sample of investing countries according to their own level of domestic ADR $\left(S_{-} A D R_{l}\right)$. We report in columns $(2 \mathrm{a})$ and $(2 \mathrm{~b})$ results when restricting the sample to investing countries featuring a level of $S_{-} A D R_{l}$, respectively, below or above the median. The median $S_{-} A D R_{l}$ value in the group of fourteen investing countries included is equal to 4, with only two countries placed (strictly) below the median and four placed (strictly) above. The very large number of countries taking a median value does not allow us either to ignore them or to arbitrarily include them in either group. To ensure enough variability we then confront two groups of countries, one (weakly) below the median and the other (weakly) above the median, both of them including the median countries. Focusing on the coefficient of the $S_{-} A D R_{j}$ index we observe that the impact of this variable is higher for investors benefiting relatively weak investor protection at home (0.18 versus 0.12$)$.

To test the statistical significance of this difference, we report in column (3) the results from a regression

\footnotetext{
${ }^{12}$ It is worth noting that the endogeneity critique often raised against La Porta et al. (1998) is much less an issue here. In fact, in La Porta et al. (1998) the direction of causality between investor protection laws and development of financial markets (aggregate asset supply) is controversial. In our setting instead the dependent variable is the bilateral foreign bias, that is, the ratio between bilateral portfolio position and market share, and the direction of causality, if any, goes arguably from investor protection to portfolio bias rather than vice versa.

${ }^{13}$ Note that any linear effect of domestic ADR on foreign investment identified by Giannetti and Koskinen (2010) is captured in our setting by investing country fixed effects.
} 
specification, run over all investing countries, which includes both $S_{-} a d r_{j}$ and its interaction term with $S_{\_} a d r_{l}$. The coefficient of the $S_{-} a d r_{j}$ factor is quite high and significant (0.31) and reflects the impact of $S_{-} a d r_{j}$ when $S_{-} a d r_{l}$ equals 0 . As far as $S_{-} a d r_{l}$ increases the effect of corporate governance in attracting foreign investment decreases, as displayed by the negative and significant coefficient of the interacted variable (-0.18). This result in consistent with Giofré (2014) and confirms that $S_{-} a d r_{l}$ significantly influences the impact of $S_{-} a d r_{j}$ on foreign portfolio investment.

We control for other destination-specific factors, potentially correlated with $S_{-} a d r_{j}$, which, if omitted, can bias the coefficients of the included regressors.

Previous literature has documented that fraudulent transactions, bribery, unenforceable contracts, legal and regulation complexity can significantly affect portfolio investments (Gelos and Wei (2005); Leuz et al. $(2009))$.

We account for two institutional variables which capture the soundness of the economic environment from a more general to a more specific level: the first one is related to (control of) expropriation risk while the second one captures the transparency of accounting rules. Control of the risk of expropriation captures government stance toward business while accounting standards are critical to corporate governance in that they render company disclosure interpretable. Aggarwal et al. (2005) find that countries with better accounting standards, shareholder rights, and legal frameworks attract more US mutual fund investment relative to benchmark indices. Their results emphasize that high-quality accounting information allows foreign investors to monitor and protect their investments and to efficiently allocate capital. Our results in column (4) emphasize a significant effect of good accounting practices and of control of risk of expropriation on foreign portfolio investment, with a similar quantitative impact (0.20).

Finally, a solid system of legal enforcement could substitute for weak "law on the books": Active and well functioning courts can serve as recourse for investors aggrieved by management (La Porta et al. (1998)). We control for the role of the efficiency of the judicial system in attracting foreign investments. In column (4) we show that this variable has a positive significant effect (0.19).

The introduction of these control factors moderately increases the impact of $S_{-} a d r_{j}$ (from 0.31 to 0.34 ) and leaves almost unchanged the negative impact of the variable interacted with $S \_a d r_{l}(-0.18)$.

*TABLE 4 about here* 


\subsubsection{Robustness}

The key idea of the paper is to propose and test a possible interpretation for the role of domestic investor protection in international portfolio choice. A necessary condition to achieve this goal is to provide robust evidence that the "preliminary condition" holds: in Table 4 we control that this evidence is not due to the particular time period considered and to measurement or definitional issues.

Financial crisis and financial regulation The time period we are considering may be non-neutral for the analysis we perform since it encompasses the initial phase of the global financial crisis and the evolution in financial market regulation in major economies. These events need to be accounted for both because they might have had a direct impact on international diversification incentives and, more importantly, because these factors can affect the way international portfolios respond to investor protection indexes.

During the global financial crisis of 2007-2008 an unprecedented large number of financial institutions collapsed or were bailed out by governments. While this paper has not the ambition to investigate the complex impact of the crisis on international portfolios, nevertheless it cannot neglect the phenomenon. Column (1) of Table 4 reports results when a dummy for the 2007-2008 crisis is included while column (2) also contains an interaction term between the index of investor protection and the crisis dummy. Indeed, it may be the case that the relevance of corporate governance for international portfolio choice varies during the crisis period. Our findings do not point to any significant effect - either direct or indirect- of the 20072008 crisis on foreign portfolios. Of course we cannot infer from these findings that the crisis had no impact on international diversification: such an analysis requires a whole picture of the crisis -while here we restrict to the initial phase only- and, more importantly, necessitates a rigorous investigation of the evolution of the crisis and its forms of contagion across countries.

Major changes occurred in the regulatory framework of developed economies, in the aftermath of a number of high-profile scandals. In 2002 the United States' Congress passed the Sarbanes-Oxley Act, with a deadline of November 2004 for full compliance by firms. The Act is the most important legislation affecting corporate financial reporting enacted in the United States since the 1930s. It not only imposes additional disclosure requirements, but more importantly, proposes substantive corporate governance mandates.

In response, major economies emulated the Sarbanes-Oxley Act and the related rules adopted by US exchanges and securities regulators. In Australia, the Corporate Law Economic Reform Program Act, a modification of the Corporations Act 2001 which governs corporate law, was enacted in July 2004 . In 
2005, the government of Canada's province of Ontario passed the Budget Measures Act, known as Bill 198, which closely duplicates the regulatory requirements contained in the Sarbanes-Oxley Act. The deadline for compliance for Canadian firms was near the end of 2006. In June 2006, the Financial Instruments and Exchange Act, that is the main statute codifying securities law and regulating securities companies in Japan, was promulgated. It is often referred to as the Japanese Sarbanes-Oxley Act and became effective in April 2008 for companies listed in Japan. In July 2008 the 8th EU directive 2006/43/EC of the European Parliament came into force in member states. This Directive is generally considered as the European Sarbanes-Oxley Act.

While the impact of existing securities legislation is still under debate, these mandatory statutes brought about deep changes on the regulatory and supervisory framework which might have affected the perception of investor protection in the system. We construct a dummy for financial system regulation, which is equal to 1 for the countries involved, in the relevant years (0 otherwise). ${ }^{14}$ In column (3) of Table 4 we check for a direct effect of this variable on foreign investment. The coefficient is not statistically different from zero. In column (4) we test for an indirect effect of the regulatory dummy, which is interacted with $S_{-} a d r_{j}$ : we find again a non significant coefficient of the interaction term. After controlling for the evolution of the regulatory framework, both the coefficient of $S_{-} a d r_{j}$ and the coefficient of its interaction with $S_{-} a d r_{l}$ are only modestly affected. These findings are far from being exhaustive. In this context we capture an average effect of change in regulation: a careful analysis of this issue, far beyond the scope of the present paper, should take into account specificities of different regulations and investigate specifically the potentially asymmetric effect of various rules, depending on preexisting levels of investor protection.

Alternative definition of market share and ADR index Dahlquist et al. (2003) estimate the fraction of shares closely held across fifty-one countries, finding that on average 32 percent of shares are not available for trading and cannot therefore be held by foreign investors. This induces a measurement error in the size of domestic and foreign bias neglected by previous literature. These authors construct the world float portfolio, which considers only shares that can actually be held by investors. Following Dahlquist et al. (2003), we consider the fraction of closely held shares as exogenous, correct the asset supply and compute the corrected bias measure. In column (5) the share in the world float portfolio replaces the market share as denominator of the foreign bias measure, our dependent variable. Results after adopting the world float

\footnotetext{
${ }^{14}$ See Appendix A.2 for further details.
} 
portfolio confirm previous findings with an even stronger impact of investor protection rights. ${ }^{15}$

Finally, we adopt as an alternative to $S_{-} a d r$, the "revised" ADR index $\left(R_{-} a d r\right)$ as defined in Djankov et al. (2008). The index relies on the same basic dimensions of corporate law of the original La Porta et al. (1998) index but defines them with more precision. Our results appear robust to the alternative revised specification of antidirector rights: both the coefficient of the $R_{-} A D R_{j}$ index and the coefficient of its interaction with $R_{-} A D R_{l}$ are significant, in statistical and economic terms.

The findings contained in Table 4 provide robust evidence that the "preliminary condition" is satisfied: domestic investor protection affects international portfolios by reducing the role played by foreign corporate governance in attracting inward investment.

\subsection{Comparative corporate governance}

\subsubsection{The S_ADR ratio}

When including investor protection as a pure destination-specific factor we implicitly assume it has the same effect on all foreign investors. Tables 3 and 4 show that it is very unlikely the case and, more specifically, that the way foreign investment depends on foreign ADR may be related to the level of domestic ADR. As formally explained in Section 2.1.2 we speculate that international portfolios are driven, rather than by foreign corporate governance scaled by its world average, by "comparative corporate governance", that is, by foreign corporate governance scaled by (a function of) domestic corporate governance $\left(\frac{S_{-} A D R_{j}}{f\left(S_{-} A D R_{l}\right)}\right)$.

In Table 5 we consider the function $f_{h}\left(S_{-} A D R_{l}\right)=S_{-} A D R_{l}$ which satisfies the "consistency condition" and investigate how foreign investment choices depend upon the $S_{-} A D R$ ratio $\left(S_{-} A D R_{j} / S_{-} A D R_{l}\right)$.

*TABLE 5 about here*

In column (1) we consider a parsimonious specification which includes the $S_{-} A D R$ ratio, the proximity variables, the crisis dummy and the regulation dummy. The coefficient of the $S_{-} A D R$ ratio is positive and statistically significant. Then the proposed measure of "comparative corporate governance" accomplishes

\footnotetext{
${ }^{15}$ Previous studies that analyze the effect of governance on foreign investments provide a mixed picture. Dahlquist et al. (2003) find that differences in investor rights and financial development across countries cannot explain the portfolio investment of US investors when including the float portfolio as determinant. However, Leuz et al. (2009) find opposite results when considering heterogeneity in governance practices across US firms: some firms can be underweighted and other overweighted resulting in no effect in the aggregate. Although keeping an aggregate perspective similar to Dahlquist et al. (2003), we shift from a US-based perspective to a cross-section of investing countries diversifying their portfolios and obtain results consistent with Leuz et al. (2009).
} 
the "significativity condition". The size of the coefficient, 0.12 , is close to the coefficient of the standard $S_{-} A D R_{j}$ index scaled by the world average estimated in column (2) of Table $3 .{ }^{16}$

This evidence implies that the impact of the two rival measures is similar on average, that is, when estimated on the overall sample of investing countries.

In column (2) we add institutional variables such are control of risk of expropriation, accounting standards and efficiency of the judicial systems. For consistency, also these covariates are included in ratio forms, i.e., as the ratio of the value taken in the destination country to the value taken in the investing country. After controlling for these factors the coefficient of the $S_{-} A D R$ ratio is only modestly affected.

To account for the possibility that investors are also influenced by the general economic conditions in the host countries, we include, in column (3), GDP growth, inflation and stock market development (in ratio forms) in order to seize the macroeconomic conditions of foreign countries (relative to domestic ones). The size and significance of the relevant coefficients are substantially unaffected by these additional controls. ${ }^{17}$

In columns (4)-(6) we run robustness checks of our findings on different sub-samples. To detect the presence of eventual cluster effects, we restrict the sample of investing countries to the European Union in column (4), and to the United States and Canada in column (5). For the EU block we can notice that, while the coefficients of the proximity variables are generally more pronounced, the coefficient of the EMU dummy is lower in size, though still large and significant. This suggests that the coefficient of the common currency dummy in the full sample specification partially captures also a natural clustering between EU and non-EU countries. On the other hand, about two thirds of the size of the coefficient are maintained also within the EU cluster thus pointing to the importance of sharing a common currency for foreign investment. Column (5) consider the US-Canada block: the coefficients are generally lower in size -including the coefficient of the $S_{-} A D R$ ratio- and less precisely estimated, due to the dramatically lower number of observations. ${ }^{18}$ The financial crisis dummy, never significant in other specifications, is positive and statistically significant: interestingly, investors residing in the United States - the country from which the financial crisis was originated- and in Canada - a country deeply connected with the United States- diversify more their portfolio abroad after 2007. Column (6) shows the results when the investment opportunity set is restricted to OECD countries, that is when Hong Kong and Singapore are dropped out of the sample.

\footnotetext{
${ }^{16}$ We confront the coefficient of column (1) in Table 5 with the coefficient of column (2) of Table 3 because other specifications also include the interaction term $\left(S_{-} a d r_{j} \cdot S_{-} a d r_{l}\right)$ so that the coefficients of $S_{-} a d r_{j}$ are not directly comparable.

${ }^{17}$ These variables are not statistically significant and their size is economically negligible.

${ }^{18}$ The absence of variability prevents the estimation of the coefficient of the EMU dummy when the sample of investing countries is restricted to non-EMU countries.
} 
The aim is to control for explicit or implicit restrictions about non-OECD foreign investments, especially for pension funds and life insurance companies. ${ }^{19}$

The coefficient of the $S_{-} A D R$ ratio remains positive and statistically significant also under different sample specifications: the linear function, satisfying the"consistency condition", provides a robust and consistent coefficient for the "comparative corporate governance" factor.

*TABLE 6 about here*

\subsubsection{Alternative functional specifications}

Table 5 shows that the $S_{-} A D R$ ratio is a possible driver of foreign investment. We have to show that it may be preferable to the standard $S_{-} A D R_{j}$ index scaled by world average because it is independent from the degree of domestic investor protection. In columns (1a)-(1b) of Table 6 we test the hypothesis that the coefficient of the $S_{-} A D R$ ratio is constant across investing countries featuring different levels of investor protection at home. Similarly to columns (2a)-(2b) in Table 3, we split the sample of investing countries into those below (or equal to) the median and those above (or equal to ) the median. The coefficient of the $S_{-} A D R$ ratio is 0.154 in column (1a) and 0.147 in column (1b). At the bottom of the estimates we report results on the test for the validity of the "effectiveness condition". We perform a Wald test relative to the null hypothesis of equality of coefficients of the $S_{-} A D R$ ratio for the two groups of countries. We report the Chi-square statistic $(\chi)$ and the corresponding probability. The test-statistic is very low $(0.291)$ and the corresponding probability very high (0.590), thus providing support to the hypothesis of equal coefficients.

These results corroborate the goodness of the $A D R$ ratio as a consistent measure to capture the corporate governance motives leading international portfolio choice. Below we confront this index with alternative measures.

In Table 6 we label the variable capturing corporate governance by $\left(S_{-} A D R_{j} / f\left(S_{-} A D R_{l}\right)\right)$. At the bottom of each couple of columns, $(\# \mathrm{a})$ and $(\# \mathrm{~b})$, the corresponding $f\left(S_{-} A D R_{l}\right)$ is reported. For the columns (1a)-(1b) the variable adopted is the $S_{-} A D R$ ratio $\left(S_{-} A D R_{j} / S_{-} A D R_{l}\right)$, i.e., $f(x)=x$ (where $\left.x=S_{-} A D R_{l}\right)$.

We recall that the "consistency condition" imposes that $S_{-} A D R_{l}=\sup f_{n}\left(S_{-} A D R_{l}\right)$ : the analysis performed so far relies on a function belonging to the (boundary of the) set of possible functions.

\footnotetext{
${ }^{19}$ According to Davis (2001), geographical constraints to institutional investors should be negligible for the sample of investing countries and the period analyzed here.
} 
Let us consider a function lying outside of the feasibility set in order to test if it does also satisfy the "effectiveness condition" (against what our theory predicts).

In columns (2a)-(2b) we run the same regression as in columns (1a)-(1b) with a different functional specification $f\left(S_{-} A D R_{l}\right)$. We adopt an exponential function $f(x)=e^{x}$ which dominates the linear function for any value of $x$ in the range $[1, \infty)$. The coefficients of the "comparative corporate governance" factors differ remarkably across the two groups (0.510 versus 2.102$)$ as captured by the high Chi-square and the very low corresponding probability: the hypothesis of equal coefficients is strongly rejected by the data thus providing support to our theory.

When choosing $f_{h}\left(S_{-} A D R_{l}\right)=S_{-} A D R_{l}$, we consider a function which dominates the region of all $f_{n}$ feasible functions.

In columns (3a)-(3b) we select an alternative function lying within the feasibility set, $f(x)=\log (x)$, which is dominated by $f(x)=x$ for any value of $x$ in the range $[1, \infty)$.

The coefficients of the "comparative corporate governance" factors in the two groups of countries are very close, 0.054 versus 0.050 and the test-statistics confirm that the data do not reject the hypothesis of equal coefficients.

The logarithmic function is hence, in abstract mathematical terms, a suitable functional specification: it satisfies the "consistency condition", the "significativity condition" and the "effectiveness condition".

It is worth stressing here that economic validity and mathematical validity are two distinct concepts.

In Table 7 we report the Chi-square statistic and the corresponding probability attached to different functional specifications of $f\left(S_{-} A D R_{l}\right)$. The shadowed area highlights the functions satisfying the "consistency condition": they appear all to fulfil the "efficiency condition". The function specifications out of the shadowed area, instead, fall outside of the feasibility region since they dominate the linear function: they fail to satisfy the "effectiveness condition" as the hypothesis of being invariant to the degree of domestic corporate protection of the investors is rejected by the data.

*TABLE 7 about here*

Within the shadowed area the logarithmic function satisfies all conditions and is then eligible as a candidate function to capture the role of domestic investor protection. Nevertheless, it has some undesirable properties for our purposes: first, the economic impact of the "comparative corporate governance factor", captured by the size of the corresponding coefficients in columns (3a)-(3b) of Table 6 , is one third compared 
with the corresponding values in columns (1a)-(1b); second, it has a concave curvature which requires an ad hoc convincing economic interpretation. An analogue reasoning applies to the function $f(x)=x^{1 / 2}$.

To further emphasize the need of an economic rationale behind our choices, note that any function $f(x)=q x$, with $0<q<1$, is also eligible as a candidate function, with a corresponding coefficient that is equal to the coefficient of the $A D R$ ratio multiplied by $q$. Being linear, it belongs to the feasibility set and it necessarily delivers the same Chi-square as the $A D R$ ratio $(f(x)=x)$ so as to satisfy also the "effectiveness condition". The inference from a pure mathematical to an economic ground needs however some caution. Following our interpretative approach, the parameter $q$ represents the weight investors attach to domestic corporate governance when computing the (perceived) world average index. While any $q$ is formally equivalent, a $q$ lower than one is economically acceptable only if not excessively small. A very low $q$ has in fact controversial implications: on the one hand, if the domesticweight is too low then the complementary foreign weight is high enough to make the approximation $\overline{S_{-} A D R} \simeq f\left(S_{-} A D R_{l}\right)$ no longer valid; on the other hand, the size of the coefficient of the "comparative corporate governance" can shrink up to the point of loosing any economic relevance. ${ }^{20}$

\section{Conclusions}

The degree of domestic investor protection affects the role of foreign corporate governance in international portfolio allocation. In particular the impact of the index of foreign corporate governance scaled by the world average index negatively depends on the level of shareholder rights protection enjoyed by investors at home.

We conjecture that the world average index can be asymmetrically perceived across investing countries because of the different weight each investor attaches to the various components of the index. In particular, the weight attached to the domestic component can be dominating. Since information asymmetries between foreign and local investors are particularly severe with respect to the evaluation of a firm's governance structure, investors are supposed to observe domestic corporate governance with much higher precision than foreign corporate governance. As a consequence, investors may attach a superior degree of reliability -and therefore a higher weight- to the index of domestic investor protection. If this weight in the world average

\footnotetext{
${ }^{20}$ A linear function with a $q$ larger than one, though it necessarily satisfies the "effectiveness condition", is instead not eligible as a candidate function: it does not satisfies the "consistency condition" as it dominates $f(x)=x$. Economically, a $q$ larger than one would imply that investors attach to domestic corporate governance a weight larger than one in the construction of the world average index.
} 
index is large enough then the average can be approximated by a function of the domestic index. In this setting, the ratio foreign to domestic antidirector rights index is a consistent common driver of international portfolios.

Traditional economic theory posits that people have full information and are able to process this information to maximize a utility function in which all of the relevant constraints and preferences are included and weighed appropriately (Simon (1959)). Behavioral economists question these assumptions and study decisions in the face of incomplete information, limited cognitive resources, and biases (for example, Thaler (1991); Heath and Tversky (1991); Kahneman (2003)).

Our interpretative approach builds on the "comparative ignorance" theory developed by Fox and Tversky (1995) and Fox and Weber (2002): individuals make a choice by comparing their knowledge on the relevant domain to their knowledge in other domains or to others' knowledge in the relevant domain. To transpose this concept in our specific case, we conjecture that investors are driven by a "comparative corporate governance" index: they decide how much to invest abroad according to foreign countries' governance practices relative to their own. After a rigorous test, this thesis is not rejected by the data.

Our analysis corroborates the conjecture of a behavioral bias spurring out of information asymmetries and thus provides support to the more general concept that information constraints and behavioral biases are intertwined. These findings entail interesting policy implications: to remove potential impediments to individual financial well-being, any effort aimed to spread among investors the awareness of their behavioral and heuristic biases can be useless, or to a large extent insufficient, if not accompanied with a parallel effort to remove investment barriers and information asymmetry. 


\section{Table 1. Domestic stock market}

This table reports the domestic share and the market share of each investing country. The reported figure are averages over the 2001-2008 period. Column (c) reports the Spamann antidirector rights index (S_ADR).

Source: International Financial Statistics (IMF), Datastream (Thomson Financial) and Spamann (2010).

\begin{tabular}{lccc}
\hline & \multicolumn{3}{c}{ Domestic market } \\
\cline { 2 - 4 } & $\begin{array}{c}\text { domestic } \\
\text { share }\end{array}$ & market share & S_ADR 1 \\
& (a) & (b) & (c) \\
\cline { 2 - 4 } Austria & 0.369 & 0.003 & 4 \\
Belgium & 0.478 & 0.007 & 2 \\
Finland & 0.557 & 0.006 & 4 \\
France & 0.661 & 0.048 & 5 \\
Germany & 0.497 & 0.036 & 4 \\
Italy & 0.544 & 0.022 & 4 \\
Netherlands & 0.357 & 0.018 & 4 \\
Spain & 0.772 & 0.019 & 6 \\
Canada & 0.823 & 0.030 & 4 \\
Denmark & 0.531 & 0.004 & 4 \\
Japan & 0.883 & 0.106 & 5 \\
Sweden & 0.533 & 0.010 & 4 \\
United Kingdom & 0.652 & 0.084 & 5 \\
United States & 0.814 & 0.412 & 2 \\
\hline \multirow{2}{*}{ correlation } & 0.236 & -0.417 & 0.050 \\
\hline
\end{tabular}




\section{Table 2. Foreign stock markets}

This table reports the average foreign share (a), the market share (b), the average foreign bias (c) and the standard deviation of foreign bias (d) displayed by the fourteen investing countries in each destination country index (head of rows) included in the opportunity set. The reported figure are averages over the 2001-2008 period. The average foreign share in country $j$ is computed as simple average of the portfolio share in country $j\left(w_{l j}\right)$ by different investing countries $l$. The average foreign bias in country $j$ is computed as simple average of the bias in country $j\left(w_{l j} / M S_{j}\right)$ by different investing countries $l$. The standard deviation of foreign bias in country $j$ is computed as the cross-sectional standard deviation around the mean of country $l$ 's foreign bias in country $j$. Column (e) reports the Spamann antidirector rights index of the destination countries.

Source: Coordinated Portfolio Investment Survey (IMF), Datastream (Thomson Financial) and Spamann (2010).

\begin{tabular}{|c|c|c|c|c|c|}
\hline & \multicolumn{5}{|c|}{ Foreign market } \\
\hline & $\begin{array}{l}\text { average } \\
\text { foreign } \\
\text { share } \\
\text { (a) } \\
\end{array}$ & $\begin{array}{c}\text { market share } \\
\text { (b) }\end{array}$ & $\begin{array}{c}\text { average } \\
\text { foreign } \\
\text { bias } \\
\text { (c) } \\
\end{array}$ & $\begin{array}{c}\text { st. dev. } \\
\text { foreign bias } \\
\text { (d) } \\
\end{array}$ & $\begin{array}{c}\text { S_ADR } \\
\text { (e) } \\
\end{array}$ \\
\hline Austria & 0.001 & 0.003 & 0.451 & 0.349 & 4 \\
\hline Belgium & 0.003 & 0.007 & 0.434 & 0.381 & 2 \\
\hline Finland & 0.006 & 0.006 & 1.007 & 0.933 & 4 \\
\hline France & 0.030 & 0.048 & 0.637 & 0.440 & 5 \\
\hline Germany & 0.027 & 0.036 & 0.766 & 0.801 & 4 \\
\hline Italy & 0.010 & 0.022 & 0.448 & 0.242 & 4 \\
\hline Netherlands & 0.016 & 0.018 & 0.887 & 0.518 & 4 \\
\hline Portugal & 0.001 & 0.002 & 0.404 & 0.466 & 4 \\
\hline Spain & 0.008 & 0.019 & 0.437 & 0.252 & 6 \\
\hline Australia & 0.003 & 0.020 & 0.174 & 0.163 & 4 \\
\hline Canada & 0.003 & 0.030 & 0.106 & 0.136 & 4 \\
\hline Denmark & 0.002 & 0.004 & 0.366 & 0.396 & 4 \\
\hline Japan & 0.019 & 0.106 & 0.180 & 0.103 & 5 \\
\hline Mexico & 0.001 & 0.006 & 0.175 & 0.174 & 3 \\
\hline Sweden & 0.011 & 0.010 & 1.100 & 2.145 & 4 \\
\hline United Kingdom & 0.039 & 0.084 & 0.466 & 0.237 & 5 \\
\hline United States & 0.088 & 0.412 & 0.213 & 0.151 & 2 \\
\hline South Korea & 0.003 & 0.013 & 0.224 & 0.182 & 6 \\
\hline Hong Kong & 0.003 & 0.025 & 0.132 & 0.113 & 4 \\
\hline \multirow[t]{2}{*}{ Singapore } & 0.001 & 0.006 & 0.228 & 0.188 & 4 \\
\hline & $(\mathrm{a} ; \mathrm{e})$ & $(\mathrm{b} ; \mathrm{e})$ & $(\mathrm{c} ; \mathrm{e})$ & $(\mathrm{d} ; \mathrm{e})$ & \\
\hline correlation & -0.248 & -0.358 & 0.044 & -0.047 & \\
\hline
\end{tabular}




\section{Table 3. Foreign investment and foreign corporate governance}

This table reports results of the feasible GLS regression as in Section 2.1 in the text. The dependent variable is the foreign portfolio bias, i.e., the ratio of portfolio share to market share, $\left(w_{l j} / M S_{j}\right)$, where the subscript $l j$ represents the couple investment country $l$-destination country $j$. Further details on the derivation of the dependent variable are provided in Appendix A.1. In column (2a) and (2b) investing countries are split according to their $S_{-} A D R_{l}$ into those below (or equal to) the median and those above (or equal to ) the median. Each regressor $X$ (dummy variables excluded) is expressed as the ratio of $X$ to its world average. Further details on the variables included as regressors are provided in Appendix A.2. Constants, investing country dummies and time dummies are included but not reported. Cross-section weights standard errors (d.f. corrected) are reported in parentheses. $* * *, * *$, and * indicate significance at the 1,5 , and $10 \%$ levels, respectively.

\section{Foreign corporate governance: foreign/world average}

(1)

distlj

dum_langlj

dum_border $r_{j}$

dum_EMUlj

dum_eq_leg_origin $1 \mathrm{j}$

S_adr ${ }_{j}$

S_adr $*$ S_adr

contr_risk_exprj

account $_{j}$

eff_jud ${ }_{j}$
(2)

(2a)

(2b)

$-0.254 * * *$

$-0.114 * * *$

$-0.124 * * *$

( 0.015 )

$0.043 *$

( 0.015 )

$0.059 * *$

( 0.033 )

0.192 ***

( 0.025 )

0.513 ***

( 0.026 )

$0.509 * * *$

( 0.034 )

( 0.028 )

( 0.028 )

0.306 ***

0.449 ***

( 0.036 )

0.313 ***

( 0.023 )

0.073 ***

$0.070 * * *$

$0.163 * * *$

( 0.018 )

( 0.018 )

0.124 ***

( 0.027 )

( 0.030 )

0.141 ***

( 0.025 )

0.182 ***

( 0.039 )
-0.173 ***

( 0.018 )

$0.116 * * *$

( 0.032 )

0.481 ***

( 0.032 )

$0.258 * * *$

( 0.025 )

0.080 ***

( 0.021 )

0.117 ***

( 0.031$)$
(3)

(4) $\begin{array}{cc}-0.122 & * * * \\ 0.015) & (0.112 * * *\end{array}$

0.056 ** $\quad 0.001$

$(0.026) \quad(0.027)$

0.516 *** $0.532 * * *$

$(0.028) \quad(0.029)$

0.304 *** $0.332 * * *$

$(0.023) \quad(0.026)$
$0.069)$

$0.069 * * * \quad 0.141 * * *$

$\left(\begin{array}{ll}0.018) \quad(0.019)\end{array}\right.$

0.312 *** 0.343 ***

$(0.116) \quad(0.117)$

$-0.183 *-0.181 *$

$(0.106) \quad(0.107)$

$0.203 *$

( 0.110$)$

$0.204 * * *$

( 0.056$)$

$0.187 * * *$

( 0.056 )

\begin{tabular}{|c|c|c|c|c|c|c|}
\hline sample & full & full & $\mathrm{S} \_\mathrm{ADR} \leq \mathrm{median}$ & $\mathrm{S}_{-} \mathrm{ADR} \mathrm{D} \geq$ median & full & full \\
\hline \#obs & 2110 & 2110 & 1512 & 1806 & 2110 & 2110 \\
\hline $\operatorname{Adj}-R^{2}$ & 0.48 & 0.48 & 0.44 & 0.42 & 0.48 & 0.53 \\
\hline
\end{tabular}




\section{Table 4. Foreign investment and foreign corporate governance: robustness}

This table reports results of the feasible GLS regression as in Section 2.1 in the text. The dependent variable is the foreign portfolio bias, i.e., the ratio of portfolio share to market share, $\left(w_{l j} / M S_{j}\right)$, where the subscript $l j$ represents the couple investment country $l$-destination country $j$. Further details on the derivation of the dependent variable are provided in Appendix A.1. In column (5) the dependent variable is foreign portfolio bias corrected for the fraction of shares closely held Dahlquist et al. (2003). Further details on the variables included as regressors are provided in Appendix A.2. Constants, investing country fixed effects and time dummies are included but not reported. Cross-section weights standard errors (d.f. corrected) are reported in parentheses. $*^{* *}, *^{*}$, and * indicate significance at the 1,5 , and $10 \%$ levels, respectively.

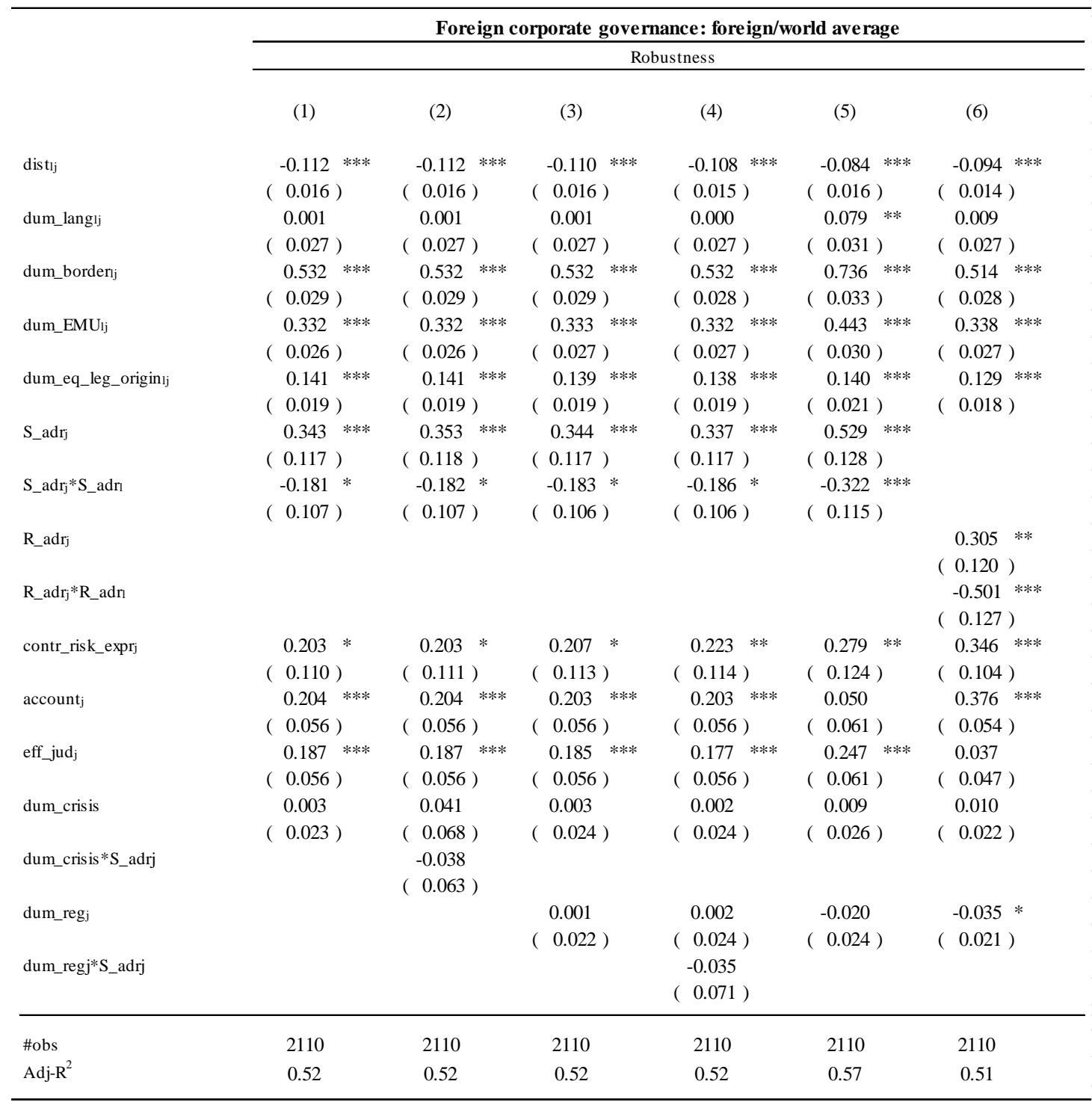




\section{Table 5. Foreign investment and "comparative corporate governance"}

This table reports results of the feasible GLS regression as in Section 2.1 in the text. The dependent variable is the foreign portfolio bias, i.e., the ratio of portfolio share to market share, $\left(w_{l j} / M S_{j}\right)$, where the subscript $l j$ represents the couple investment country $l$-destination country $j$. Further details on the derivation of the dependent variable are provided in Appendix A.1. In column (3), further controls seizing the macroeconomic conditions of source and host countries are included (GDP growth, inflation rate, stock market development). Columns (4) and (5) restrict the sample of investing economies to EU countries and to the United States and Canada, respectively. Column (6) restricts the sample of destination economies to OECD countries, i.e. excludes Hong Kong and Singapore. Details on the variables included as regressors are provided in Appendix A.2. Constants, investing country dummies and time dummies are included but not reported. Cross-section weights standard errors (d.f. corrected) are reported in parentheses. ***,**, and * indicate significance at the 1,5 , and $10 \%$ levels, respectively.

\begin{tabular}{|c|c|c|c|c|c|c|}
\hline & \multicolumn{6}{|c|}{ Comparative corporate governance: foreign/home } \\
\hline & \multirow[b]{2}{*}{ (1) } & \multirow[b]{2}{*}{ (2) } & \multirow[b]{2}{*}{ (3) } & \multicolumn{3}{|c|}{ Robustness: sample specification } \\
\hline & & & & (4) & $(5)$ & (6) \\
\hline $\operatorname{dist}_{1 j}$ & $\begin{array}{l}-0.122 * * * \\
(0.015)\end{array}$ & $\begin{array}{l}-0.105 * * * \\
(0.015)\end{array}$ & $\begin{array}{l}-0.103 * * * \\
(0.015)\end{array}$ & $\begin{array}{l}-0.432 * * * \\
(0.035)\end{array}$ & $\begin{array}{c}-0.033 \\
(0.025)\end{array}$ & $\begin{array}{l}-0.157 * * * \\
(0.022)\end{array}$ \\
\hline dum_lang ${ }_{\mathrm{lj}}$ & $\begin{array}{c}0.054 * * \\
(0.025)\end{array}$ & $\begin{array}{c}0.008 \\
(0.027)\end{array}$ & $\begin{array}{c}0.008 \\
\left(\begin{array}{l}0.027 \\
)\end{array}\right.\end{array}$ & $\begin{array}{l}0.147 \text { *** } \\
(0.034)\end{array}$ & $\begin{array}{c}-0.026 \\
(0.016)\end{array}$ & $\begin{array}{c}0.019 \\
(0.031)\end{array}$ \\
\hline dum_borderlj & $\begin{array}{l}0.514{ }^{* * *} \\
(0.028)\end{array}$ & $\begin{array}{l}0.529 * * * \\
(0.028)\end{array}$ & $\begin{array}{l}0.529 * * * \\
(0.028)\end{array}$ & $\begin{array}{l}0.520 * * * \\
(0.033)\end{array}$ & $\begin{array}{l}0.128 \text { *** } \\
(0.036)\end{array}$ & $\begin{array}{l}0.500 * * * \\
(0.031)\end{array}$ \\
\hline dum_EMUlj & $\begin{array}{l}0.306 * * * \\
(0.023)\end{array}$ & $\begin{array}{l}0.332 * * * \\
(0.027)\end{array}$ & $\begin{array}{l}0.331 * * * \\
(0.027)\end{array}$ & $\begin{array}{l}0.187 * * * \\
(0.032)\end{array}$ & & $\begin{array}{l}0.322 \text { *** } \\
(0.030)\end{array}$ \\
\hline dum_eq_leg_originlj & $\begin{array}{l}0.070 * * * \\
(0.018)\end{array}$ & $\begin{array}{l}0.136 \text { *** } \\
(0.019)\end{array}$ & $\begin{array}{l}0.135 * * * \\
(0.019)\end{array}$ & $\begin{array}{l}0.297 * * * \\
(0.026)\end{array}$ & $\begin{array}{c}-0.027 \\
(0.020)\end{array}$ & $\begin{array}{l}0.187 * * * \\
(0.021)\end{array}$ \\
\hline S_ADR & $0.120 * * *$ & $0.119 * * *$ & $0.116 * * *$ & $0.214 * * *$ & $0.045 * *$ & $0.137 * * *$ \\
\hline S_ADR & $(0.025)$ & $(0.028)$ & $(0.028)$ & $(0.036)$ & $(0.021)$ & $(0.034)$ \\
\hline contr_risk_exprj & & $0.374 * * *$ & $0.388 * * *$ & $-0.778 * * *$ & $-0.159 *$ & 0.004 \\
\hline contr_risk_expr & & $(0.133)$ & $(0.134)$ & $(0.230)$ & $(0.095)$ & $(0.182)$ \\
\hline$\frac{\text { account }_{j}}{\text { account }_{1}}$ & & $\begin{array}{l}0.279 * * * \\
(0.059)\end{array}$ & $\begin{array}{l}0.279 * * * \\
(0.059)\end{array}$ & $\begin{array}{l}0.4533^{* * *} \\
(0.080)\end{array}$ & $\begin{array}{l}0.215{ }^{* * *} \\
(0.045)\end{array}$ & $\begin{array}{l}0.255 \text { *** } \\
(0.064)\end{array}$ \\
\hline$\frac{\text { eff_judj }}{\text { eff_jud }}$ & & $\begin{array}{l}0.104 * \\
(0.060)\end{array}$ & $\begin{array}{c}0.098 \\
(0.060)\end{array}$ & $\begin{array}{l}0.435 \text { *** } \\
(0.084)\end{array}$ & $\begin{array}{c}0.049 \\
(0.049)\end{array}$ & $\begin{array}{l}0.306 \text { *** } \\
(0.076)\end{array}$ \\
\hline dum_crisis & $\begin{array}{c}0.003 \\
(0.023)\end{array}$ & $\begin{array}{c}0.004 \\
(0.023)\end{array}$ & $\begin{array}{c}0.004 \\
(0.024)\end{array}$ & $\begin{array}{c}-0.014 \\
(0.032)\end{array}$ & $\begin{array}{l}0.045{ }^{* * *} \\
(0.015)\end{array}$ & $\begin{array}{c}-0.010 \\
(0.024)\end{array}$ \\
\hline dum_reg ${ }_{j}$ & $\begin{array}{c}0.031 \\
(0.021)\end{array}$ & $\begin{array}{c}-0.005 \\
(0.022)\end{array}$ & $\begin{array}{c}-0.005 \\
(0.022)\end{array}$ & $\begin{array}{l}0.086 \text { *** } \\
(0.032)\end{array}$ & $\begin{array}{l}0.032{ }^{* *} \\
(0.016)\end{array}$ & $\begin{array}{c}0.004 \\
(0.182)\end{array}$ \\
\hline sample & full & full & full & UE & US-Can & OECD \\
\hline macroeconomics controls & no & no & yes & no & no & no \\
\hline \#obs & 2110 & 2110 & 2110 & 1654 & 304 & 1780 \\
\hline Adj- $R^{2}$ & 0.48 & 0.52 & 0.52 & 0.50 & 0.30 & 0.51 \\
\hline
\end{tabular}


Table 6. Foreign investment and "comparative corporate governance": alternative $f\left(S_{-} A D R_{l}\right)$

This table reports results of the feasible GLS regression as in Section 2.1 in the text. The dependent variable is the foreign portfolio bias, i.e., the ratio of portfolio share to market share, $\left(w_{l j} / M S_{j}\right)$, where the subscript $l j$ represents the couple investment country $l$-destination country $j$. Further details on the derivation of the dependent variable are provided in Appendix A.1. Columns (\#a) and (\#b) refer to investing countries with $S_{-} A D R_{l}$, respectively, below (or equal to) the median and above (or equal to) the median. The table reports statistics (Chi-square and probability) of the Wald test on the null hypothesis of equal coefficients of the $S_{-} A D R_{j} / f\left(S_{-} A D R_{l}\right)$ variable in (\#a) and (\#b) columns. Details on the variables included as regressors are provided in Appendix A.2. Constants, investing country dummies and time dummies are included but not reported. Cross-section weights standard errors (d.f. corrected) are reported in parentheses. ***, **, and * indicate significance at the 1,5 , and $10 \%$ levels, respectively.

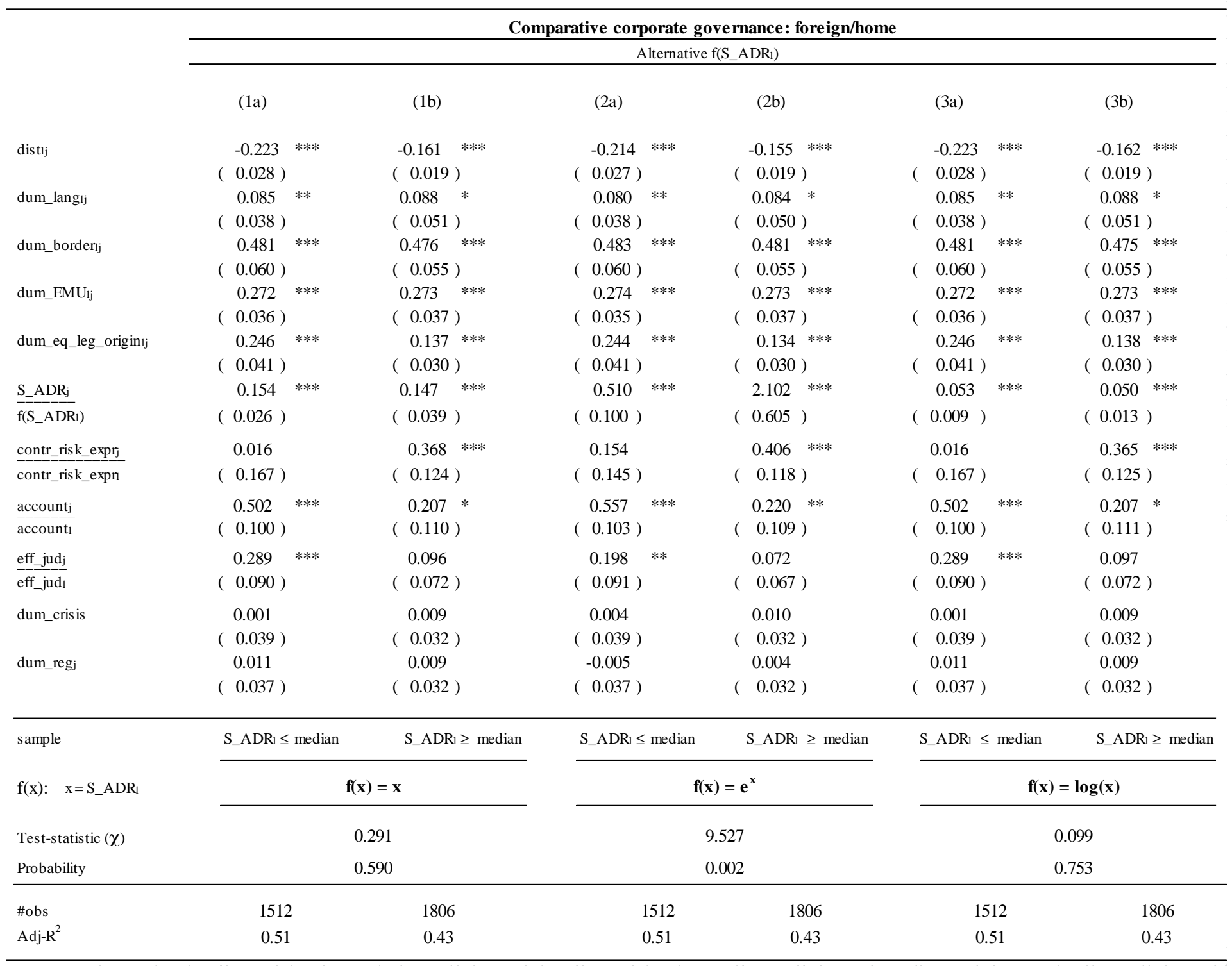




\section{Table 7. Test on different $f\left(S_{-} A D R_{l}\right)$}

The table reports, for different function specifications, test-statistics (Chi-square and probability) relative to the Wald test on the null hypothesis of equal coefficient of the $S_{-} A D R_{j} / f\left(S_{-} A D R_{l}\right)$ factor between countries with $S_{-} A D R_{l}$ below (or equal to) the median and those with $S_{-} A D R_{l}$ above (or equal to) the median. The shadow area highlights the function specifications for which the "effectiveness condition" is satisfied, i.e., the hypothesis of equal coefficients is not rejected.

\begin{tabular}{|c|c|c|}
\hline \multicolumn{3}{|c|}{ Test across alternative $\mathbf{f}\left(\mathbf{S}_{-}{ }^{A D D R} \mathbf{R}_{\mathbf{l}}\right)$} \\
\hline \multicolumn{3}{|c|}{$\left(\mathrm{x}=\mathrm{S} \_\mathrm{ADR} \mathrm{I}\right)$} \\
\hline$f(x)$ & $\begin{array}{l}\text { Test statistic } \\
\qquad(\chi)\end{array}$ & Probability \\
\hline (a) & (b) & (c) \\
\hline$x^{x}$ & 14.836 & 0.000 \\
\hline$e^{x}$ & 9.527 & 0.002 \\
\hline$x^{2}$ & 4.540 & 0.033 \\
\hline $\mathrm{x}$ & 0.291 & 0.590 \\
\hline$x^{1 / 2}$ & 0.077 & 0.782 \\
\hline $\log (\mathrm{x})$ & 0.099 & 0.753 \\
\hline
\end{tabular}




\section{References}

Aggarwal, R., L. Klapper, and P. Wysocki (2005). Portfolio preferences of foreign institutional investors. Journal of Banking and Finance 29, 2919-2946.

Balta, N. and J. Delgado (2009). Home bias and market integration in the EU. CESifo Economic Studies 55, $110-144$.

Baxter, M. and U. Jermann (1997). The international diversification puzzle is worse than you think. American Economic Review 87, 170-180.

Brennan, M. and H. Cao (1997). International portfolio investment flows. Journal of Finance 52, 1851-1880.

Chan, K., V. Covrig, and L. Ng (2005). What determines the domestic bias and foreign bias? Evidence from mutual fund equity allocations worldwide. Journal of Finance 60, 1495-1534.

Cooper, I. and E. Kaplanis (1994). Home bias in equity portfolios, inflation hedging and international capital market equilibrium. Review of Financial Studies 7, 45-70.

Dahlquist, M., L. Pinkowitz, R. Stulz, and R. Williamson (2003). Corporate governance and the home bias. Journal of Financial and Quantitative Analysis 38, 87-110.

Davis, E. (2001). Portfolio regulations of life insurance companies and pension funds. Discussion Paper PI-0101 The Pensions Institute, Birckbeck College, London.

Djankov, S., R.La Porta, F. Lopez-de-Silanes, and A. Shleifer (2008). The law and economics of self-dealing. Journal of Financial Economics 88, 430-465.

Fidora, M., M. Fratzscher, and C. Thimann (2007). Home bias in global bond and equity markets: The role of real exchange rate volatility. Journal of International Money and Finance 26, 631-655.

Foad, H. (2011). Immigration and equity home bias. Journal of International Money and Finance 30, 982-998.

Fox, C. and A. Tversky (1995). Ambiguity aversion and comparative ignorance. Quarterly Journal of Economics 110, 585-603.

Fox, C. and M. Weber (2002). Ambiguity aversion, comparative ignorance, and decision context. Organizational Behavior and Human Decision Processes 88, 476-498.

French, K. and J. Poterba (1991). International diversification and international equity markets. American Economic Review 81, 222-226.

Gehrig, T. (1993). An information based explanation of the domestic bias in international equity investment. Scandinavian Journal of Economics 95, 97-109.

Gelos, R. and S. Wei (2005). Transparency and international portfolio holdings. Journal of Finance 60, $2987-3020$.

Giannetti, M. and Y. Koskinen (2010). Investor protection, equity returns and financial globalization. Journal of Financial and Quantitative Analysis 45, 135-168.

Giofré, M. (2013). Investor protection rights and foreign investment. Journal of Comparative Economics 41, $506-526$. 
Giofré, M. (2014). Domestic investor protection and foreign portfolio investment. Journal of Banking and Finance forthcoming.

Grinblatt, M. and M. Keloharju (2001). How distance, language, and culture influence stockholdings and trades. Journal of Finance 56, 1053-1073.

Grubel, H. (1968). International diversified portfolios: Welfare gains and capital flows. American Economic Review 58, 1299-1314.

Guiso, L., P. Sapienza, and L. Zingales (2009). Cultural biases in economic exchange? Quarterly Journal of Economics 124, 1095-1131.

Heath, C. and A. Tversky (1991). Preference and belief: ambiguity and competence in choice under uncertainty. Journal of Risk and Uncertainty 4, 5-28.

Kahneman, D. (2003). Maps of bounded rationality: Psychology for behavioral economics. American Economic Review 93, 1449-1475.

Kang, J. and R. Stulz (1997). Why is there a home bias? an analysis of foreign portfolio equity ownership in Japan. Journal of Financial Economics 46, 3-28.

Karolyi, A. and R. Stulz (2003). Are financial assets priced locally or globally? Handbook of the Economics and Finance 1, 975-1020.

Kho, B., R. Stulz, and F. Warnock (2009). Financial globalization, governance and the evolution of the home bias. Journal of Accounting Research 47, 597-635.

La Porta, R., F. Lopez-de-Silanes, A. Shleifer, and R. Vishny (1998). Law and finance. Journal of Political Economy 106, 1113-1154.

Lane, P. (2006). Global bond portfolios and EMU. International Journal of Central Banking 2, 1-23.

Lane, P. and G. Milesi-Ferretti (2007). The international equity holdings of euro area investors. in The Importance of the External Dimension for the Euro Area: Trade, Capital Flows, and International Macroeconomic Linkages (Robert Anderton and Filippo di Mauro, eds), Cambridge University Press.

Leuz, C., K. Lins, and F. Warnock (2009). Do foreigners invest less in poorly governed firms? Review of Financial Studies 22, 3245-3285.

Levy, H. and M. Sarnat (1970). International diversification in investment portfolios. American Economic Review 60, 668-675.

Lewis, K. (1999). Trying to explain home bias in equities and consumption. Journal of Economic Literature $37,571-608$.

Li, K. (2004). Confidence in the familiar: An international perspective. Journal of Financial and Quantitative Analysis 39, 47-68.

Markowitz, H. (1952). Portfolio selection. Journal of Finance 7, 77-91.

Pesenti, P. and E. van Wincoop (2002). Can nontradables generate substantial home bias? Journal of Money, Credit and Banking 34, 25-50.

Portes, R. and H. Rey (2005). The determinants of cross-border equity flows. Journal of International Economics 65, 269-296. 
Sharpe, W. (1964). Capital asset prices: A theory of market equilibrium under the condition of risk. Journal of Finance 19, 425-442.

Simon, H. (1959). Theories of decision-making in economics and behavioral science. American Economic Review 49, 253-283.

Solnik, B. (1974). The international pricing of risk: An empirical investigation of the world capital market structure. Journal of Finance 47, 365-378.

Sorensen, B. E., Y. Wu, O. Yosha, and Y. Zhu (2007). Home bias and international risk sharing: Twin puzzles separated at birth. Journal of International Money and Finance 26, 587-605.

Spamann, H. (2010). The antidirector rights index revisited. Review of Financial Studies 23, 467-486.

Strong, N. and X. Xu (2003). Understanding the equity home bias: Evidence from survey data. Review of Economics and Statistics 85, 307-312.

Stulz, R. (1981). On the effects of barriers to international investment. Journal of Finance 36, 923-934.

Tesar, L. and I. Werner (1995). Home bias and high turnover. Journal of International Money and Finance 14, 467-492.

Thaler, R. H. (1991). Anomalies: Savings, fungibility, and mental accounts. Journal of Economic Perspectives 4, 193-205.

Thapa, C. and S. Poshakwale (2011). Investor protection and international equity portfolio investments. Global Finance Journal 22, 116-129.

Vlachos, J. (2004). Does regulatory harmonization increase bilateral asset holdings? CEPR Discussion Paper DP4417. 


\section{A Data appendix}

\section{A.1 Dependent variables}

\section{Foreign stock market portfolios}

The CPIS dataset contains information on foreign holdings only and does not include domestic positions. In order to derive the foreign portfolio positions in the overall portfolio we need to retrieve the share of foreign assets. To accomplish this objective we drew from Datastream (Thomson Financial) the stock market capitalization of all country indexes and from the International Financial Statistics (IFS) the outstanding foreign equity portfolio investments and the corresponding liabilities. Accordingly we can derive the "foreign equity share" of country $i$ at time $t, F S_{i t}{ }^{21}$

$$
F S_{i, t}=\frac{(F A)_{i, t}}{\left(M C A P_{i, t}+F A_{i, t}-F L_{i, t}\right)}
$$

where $F A$ stands for "foreign equity assets", $F L$ for "foreign equity liabilities" and $M C A P$ for "stock market capitalization". After obtaining the foreign share $F S$ it is possible to recover the share of each foreign asset in the overall portfolio.

\section{Market share}

Market shares refer to the values at the end of December of each year.

Source: Datastream, Thomson Financial

\section{World float portfolio}

The world float portfolio is a corrected value weighted portfolio obtained by multiplying the market share by a fraction taking into account the fraction of closely held shares (Dahlquist et al. (2003)). We convert our world market portfolio weights into world float portfolio weights (Dahlquist et al. (2003), Table 2). We keep the conversion coefficient invariant over the time period considered.

\section{A.2 Regressors}

To assure consistency with the theoretical framework, each variable $X$ (dummy variables excluded) enters our regression specifications as the ratio of $X$ to its world average.

\section{Proximity variables}

\section{Distance}

The distance is measured as the Great Circle distance in miles between capital cities of source $(l)$ and destination $(j)$ country. The average distance from a destination country $(j)$ is obtained as weighted (by market share) average of the distance of investing countries. The variable included in the regression is the ratio of the distance $l-j$ to the average distance.

Border dummy

Dummy variable taking value of 1 if the investing country and the destination country share a common border (0 otherwise).

Language dummy

Dummy variable taking value of 1 if the investing country and the destination country share a common language (0 otherwise)

EMU dummy (Common Currency dummy)

Dummy variable taking value of 1 if the investing country and the destination country are members of the European Monetary Union (0 otherwise). In our case, it coincides with a common currency dummy since do not belong to any other currency union.

\footnotetext{
${ }^{21}$ Fidora et al. (2007) and Sorensen et al. (2007) follow the same procedure dealing with the CPIS dataset.
} 


\section{Equal legal origin}

Dummy variable taking value 1 if the investing country and the destination country share the same legal origin of the company law or commercial code of each country (0 otherwise). The countries included in our sample belong to four legal families: English, French, German, Scandinavian.

\section{Regulation dummy}

It captures the changes in the regulatory framework. It is a destination country-specific dummy variable taking value 1 for the United States and Australia since year 2004 onward, for Canada since 2006 onward and for Japan and EU countries in year 2008 (0 otherwise).

\section{Crisis dummy}

Dummy variable taking value 1 for the year 2007 and 2008 (0 otherwise).

\section{Revised Antidirector Rights Index}

The index amends the original La Porta et al. (1998) index (Djankov et al. (2008)) and ranges from 0 (weak antidirector rights) to 6 (strong antidirector rights). The revised index relies on the same basic dimensions of corporate law, but defines them with more precision. Both the original and the revised anti-director rights indices summarize the protection of minority shareholders in the corporate decisionmaking process, including the right to vote. The index covers the following six areas: (1) vote by mail; (2) obstacles to the actual exercise of the right to vote (i.e., the requirement that shares be deposited before the shareholders' meeting); (3) minority representation on the board of directors through cumulative voting or proportional representation; (4) an oppressed minority mechanism to seek redress in case of expropriation; (5) preemptive rights to subscribe to new securities issued by the company; and (6) the right to call a special shareholder meeting. The general principle behind the construction of the revised anti-director rights index is to associate better investor protection with laws that explicitly mandate, or set as a default rule, provisions that are favorable to minority shareholders. Methodologically, the key difference between the original and revised indices of anti-director rights lies in the treatment of enabling provisions. See Djankov et al. (2008) for further details.

\section{Corrected Antidirector Rights Index}

The index is constructed by Spamann (2010). It is constructed as in La Porta et al. (1998) but a reexamination of the legal data leads to corrections for thirty-three out of forty-six countries analyzed. The correlation between corrected and original values is 0.53 .

\section{Expropriation risk}

ICR's assessment of the risk of "outright confiscation" or "forced nationalization". Scale from zero to 10 with lower scores for higher risk (La Porta et al. (1998)).

\section{Accounting rules}

Index based on information disclosure and accounting practices (La Porta et al. (1998)).

\section{Efficiency of judicial system}

Assessment of the "efficiency and integrity of the legal environment as it affects business, particularly foreign firms" produced by Business International Corporation. Scale from zero to 10 with lower scores for lower efficiency level (La Porta et al. (1998))

\section{Stock market development}

Market capitalization of listed companies (current US\$): is the share price times the number of shares outstanding. Listed domestic companies are the domestically incorporated companies listed on the country's stock exchanges at the end of the year. Listed companies does not include investment companies, mutual funds, or other collective investment vehicles.

Source: World Bank, World Development Indicators, Financial Sector.

\section{Inflation}

Inflation as measured by the consumer price index reflects the annual percentage change in the cost to the average consumer of acquiring a basket of goods and services that may be fixed or changed at specified intervals, such as yearly. The Laspeyres formula is generally used. 
Source: World Bank, World Development Indicators, Economic Policy and External Debt. GDP growth

Annual percentage growth rate of GDP at market prices based on constant local currency. Aggregates are based on constant 2005 U.S. dollars. GDP is the sum of gross value added by all resident producers in the economy plus any product taxes and minus any subsidies not included in the value of the products. It is calculated without making deductions for depreciation of fabricated assets or for depletion and degradation of natural resources.

Source: World Bank, World Development Indicators, Economic Policy and External Debt. 